\title{
Precipitation variations of Longxi, northeast margin of Tibetan Plateau since AD 960 and their relationship with solar activity
}

\author{
Liangcheng Tan $^{1,3}$, Yanjun $\mathrm{Cai}^{1}{ }^{1}$ Liang $\mathbf{Y i}^{2,3}$, Zhisheng $\mathrm{An}^{1}$, and $\mathbf{L i ~} \mathbf{A i}^{1,3}$ \\ ${ }^{1}$ State Key Laboratory of Loess and Quaternary Geology, Institute of Earth Environment, Chinese Academy of Sciences, \\ Xi'an, 710075, China \\ ${ }^{2}$ Yantai Institute of Coastal Zone Research for Sustainable Development, Chinese Academy of Sciences, Yantai, 264003, \\ China \\ ${ }^{3}$ Graduate School of Chinese Academy of Sciences, Beijing, 100039, China
}

Received: 14 September 2007 - Published in Clim. Past Discuss.: 28 September 2007

Revised: 27 November 2007 - Accepted: 4 January 2008 - Published: 20 February 2008

\begin{abstract}
The precipitation variations of Longxi area, northeast margin of the Tibetan Plateau since AD 960 are reconstructed from Chinese historical documentary records. These records show that since AD 960, the precipitation of Longxi decreased and reached the lowest level at the end of the 17th and the 18th centuries. After this period, the precipitation gradually increased. The three short wet periods of Longxi in the last millennium were: from the end of the 10th century to the early years of the 11th century, from the end of the 12th century to the early years of the 13th century and during the first half of the 20th century. The precipitation variations coincide well with variations of the Northern Hemisphere temperature and the atmospheric ${ }^{14} \mathrm{C}$ concentration, as well as the averaged ${ }^{10} \mathrm{Be}$ concentration and the reconstructed solar modulation record which show that solar activity may be an important driving force of the precipitation variations of Longxi on multi-decadal to centennial scales during the last millennium. Solar activity controls the motion of the north edge of the Asian summer monsoon by affecting the Asia summer monsoon intensity, the East Asian winter monsoon intensity and the locations of westerlies, thus further dominating precipitation variations of Longxi. Synchronous variations of Longxi precipitation and Northern Hemisphere temperature may also be ascribed to the same control of solar activity.
\end{abstract}

\section{Introduction}

The Longxi area lies at the northeast Tibetan Plateau margin and is within the transition zone to the Loess Plateau. The climate is that of the semi-arid temperature zone. Meteoro- logical records show that annual rainfall of this area varied greatly. For example, during AD 1937-2003, the lowest annual rainfall in Lanzhou was $189 \mathrm{~mm}$ in 1980 and the highest was $547 \mathrm{~mm}$ in 1978. In Longxi County, the lowest annual rainfall was $362 \mathrm{~mm}$ in 1997 and the highest was $818 \mathrm{~mm}$ in 1967. According to historical records and geographical features, we define this area as including today's Lanzhou area, Dingxi area and the close-by Wushan County, Huining County, Gangu County, Qin'an County, as shown in Fig. 1.

The Longxi area is an important origin of upstream Yellow River civilization, and it cradled the famous Majiayao culture, the Qijia culture, the Xindian culture and the Siwa culture in the Neolithic Age (An et al., 2003). Climate research of this area is critical for a good understanding of the relationship between human societal development and environmental changes. Because of the lack of geological and biological materials, high resolution climate records in this area during the past 2000 or 1000 years are still not publicly seen. However, China has abundant historical documents which contain much information on climate changes. This paper reconstructs the precipitation variations of the Longxi area since AD 960 based on related historical records. The relationship between precipitation variations of Longxi and solar activity in the last millennium are also discussed. It shows that solar activity may be an important force driving the synchronous variations of precipitation in the northeast margin of the Tibetan Plateau and the Northern Hemisphere temperature on multi-decadal to centennial scales in the last millennium.

Correspondence to: Liangcheng Tan

(tanlch@ieecas.cn)

Published by Copernicus Publications on behalf of the European Geosciences Union. 

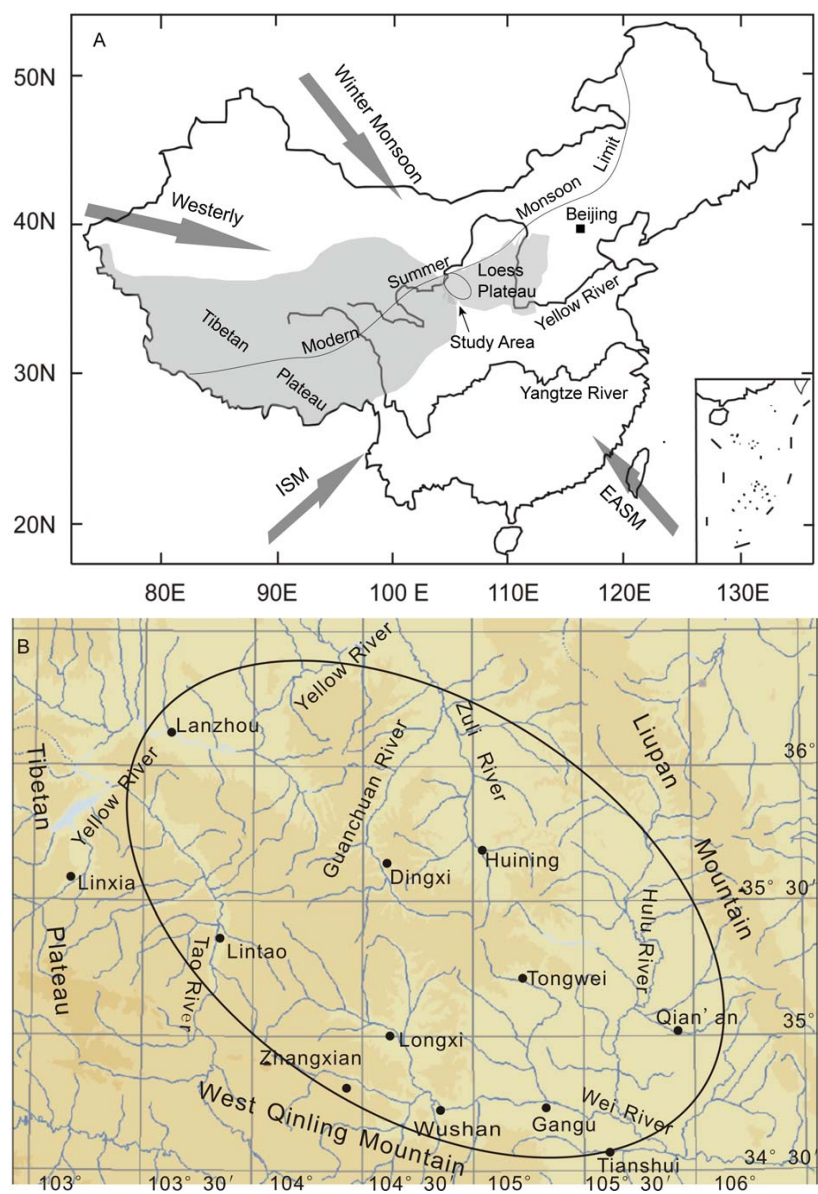

Fig. 1. Location of Longxi area (A) and the detailed landform (B). The ellipse in (A) and (B) denote Longxi area. ISM and EASM denote the Indian summer monsoon and the East Asian summer monsoon respectively.

\section{Historical documents: sources and description}

\subsection{Sources}

The historical climate records before the Ming (AD 13681644) and Qing (AD 1644-1911) Dynasty mainly came from the official chronicles of emperors called Benji and the chapter called Wuxingzhi (Five Elements Chapter) of each dynasty. The origins of historical climate records in the Ming and Qing Dynasty were abundant, including the official chronicles of the Ming and Qing Dynasty (Ming Shi and Qing Shi), Donghua Lu (Records of Donghua), Donghua Xu Lu (Extended Records of Donghua), Luzheng Xu Gao (Extended Draft of Luzheng), and local chronicles called Zhi. The historical climate documents of the early periods of the Republic of China mainly came from government reports of Gansu Province, The Rescue History of China (Deng, 1937) and local chronicles of each county. There are meteorological records from the latter periods of the Republic of China. Some documents used in this paper were also from Gansu Xin Tong Zhi (New Whole Records of Gansu), which were compiled in the reign of Emperor Guangxu (AD 18751908) of the Qing Dynasty, the Draft of Whole Records of Gansu (Liu, 1936) and the Abstract History of Gan Qing Ning Area (Mu, 1936) as well as the Catalogue of Disasters in China (Chen, 1939), the Brief Natural Disaster Records of each period of Gansu Province (Zhao, 1984) and Collection of weather records in China in the last 3000 years (Zhang, 2004). Target counties of the Longxi area have been selected as modern Dingxi City, Lanzhou City and their administrated counties, also Wushan County, Huining County, Gangu County, and Qin'an County. We also refer to historical climate records from neighboring areas, such as Pingliang, Tianshui, Longnan, Linxia and Gannan.

\subsection{Description}

The Longxi area had been under Han domination since the reign of the Northern Song Emperor Shenzong (AD 10681085). After the Northern Song Dynasty (AD 960-1127) collapsed, the Jin Dynasty (AD 1115-1234) captured Longxi in AD 1131. Later, after the Mongolians conquered Jin in AD 1234 and General Shixian Wang of Jin surrendered to Mongolians in AD 1235, the Longxi area became part of Mongolia \& Yuan Dynasty (AD 1206-1368). In the Ming and Qing periods, the Longxi area was inland of China.

The historical documentary records show that the climate in the first half of Northern Song was wet. It turned dry gradually during the latter half of the Northern Song period. We put all the drought/flood years of Longxi together during this time in Table 1. From Table 1, we can see that in Northern Song floods mostly occurred in the last decade of the 10th century and the first two decades of the 11th century, while droughts mostly occurred in 70-80's of the 11th century. During this period, there was a serious drought during AD 1078-1082. It lasted 4-5 years and affected most of Northwest China. Droughts during the Jin Dynasty occurred mainly in the latter half of the 12th century, and there was a short wet period in the early 13th century. After this, the climate turned drier in the entire Mongolian \& Yuan period.

The Ming and Qing Dynasty correspond roughly to the "Little Ice Age" of Europe (Lamb, 1965; Bradley and Jones, 1992). Because of the stable social situation and its proximity in time to the present, there were abundant historical materials and so more detailed records on climate. In general, dry climate characterizes the entire Ming and Qing periods.

In the Ming Dynasty, Longxi was extremely dry. There were two severe droughts. One lasted from the 1480's to the 1530 's - half a century - during which time nothing was recorded about any kind of wet condition. The other drought lasted even longer, from the 1580's to the end of Ming, about 65 years (Table 2). There were also records of droughts in Xi'an area (Zhu et al., 1998) and Beijing area (Tan and Cai, 2005) during these periods. These two droughts were 
Table 1. Time table of droughts and floods occurred in Longxi during the period of the Northern Song, Jin and Mongolia \& Yuan Dynasty.

\begin{tabular}{llll}
\hline Dynasty & Year & Flood & Drought \\
\hline $\begin{array}{l}\text { Northern Song } \\
\text { (AD 960-1127) }\end{array}$ & AD 900 & $964,979,990,993,994,999$ & $968,974,992$ \\
& AD 1000 & $1000,1008,1009,1010,1014,1016,1027$, & $1017,1018,1020,1025,1039,1066,1067,1070$, \\
Jin & AD 1100 & $11058,1064,1069,1077,1099$ & $1074,1076,1078,1079,1080,1081,1082,1088$ \\
(AD 1115-1234) & & $1189,1190,1191,1193,1194$ & $1102,1107,1123,1132,1136,1142,1143,1154$, \\
Mongolia \&Yuan & AD 1200 & $1205,1206,1209,1221,1225$ & $1160,1174,1176,1182,1184,1187,1197$ \\
(AD 1206-1368) & & & $1201,1212,1213,1216,1226,1248,1266,1268$, \\
& AD 1300 & $1311,1318,1320,1324,1325,1326$ & $1280,1285,1290,1295,1296$ \\
& & & $1302,1308,1312,1315,1323,1328,1329,1331$, \\
\end{tabular}

Historical documentary records mainly came from chapter Benji and Wuxingzhi of Song Shi(History of Song Dynasty)(completed at AD 1345), Jin Shi(History of Jin)(completed at AD 1344 ) and Yuan Shi(History of Yuan)(completed at AD 1370), also came from Gansu Xin Tong Zhi, Gansu Tong Zhi Gao, Abstract History of Gan Qing Ning Area and reference from Tang and Liu (1986).

Table 2. Time table of droughts and floods occurred in Longxi during the period of the Ming and Qing Dynasty.

\begin{tabular}{|c|c|c|c|}
\hline Dynasty & Year & Flood & Drought \\
\hline \multirow{4}{*}{$\begin{array}{l}\text { Ming } \\
(\text { AD 1368-1644) }\end{array}$} & AD 1300 & & 1371,1393 \\
\hline & AD 1400 & $1410,1438,1448,1461,1479$ & $\begin{array}{l}1408,1418,1426,1427,1434,1437,1439,1441, \\
1451,1455,1468,1470,1473,1474,1482,1484, \\
1485,1486,1487,1490,1491,1493,1494,1495, \\
1497\end{array}$ \\
\hline & AD 1500 & $1535,1537,1558,1570,1580,1590$ & $\begin{array}{l}1505,1506,1508,1509,1512,1520,1521,1528, \\
1529,1531,1532,1538,1539,1540,1545,1548, \\
1550,1555,1568,1581,1582,1583,1584,1585, \\
1586,1587,1588,1598,1599\end{array}$ \\
\hline & AD 1600 & $\begin{array}{l}1648,1652,1653,1654,1655,1662,1678, \\
1681,1685\end{array}$ & $\begin{array}{l}1602,1606,1609,1614,1615,1616,1621,1626, \\
1628,1629,1630,1634,1635,1636,1637,1638, \\
1639,1640,1641,1643,1651,1656,1657,1659, \\
1665,1666,1667,1668,1683,1684,1686,1690, \\
1691,1692,1693,1694,1697\end{array}$ \\
\hline \multirow[t]{3}{*}{$\begin{array}{l}\text { Qing } \\
(\text { AD 1644-1911) }\end{array}$} & AD 1700 & $\begin{array}{l}\text { 1740, 1744, } 1745,1752,1753,1755,1761, \\
1772,1785\end{array}$ & $\begin{array}{l}1701,1703,1704,1708,1712,1713,1714,1715, \\
1716,1717,1718,1719,1720,1721,1723,1728, \\
1729,1730,1735,1736,1737,1738,1742,1743, \\
1747,1749,1751,1754,1756,1758,1759,1760, \\
1762,1763,1764,1765,1766,1768,1770,1771, \\
1774,1775,1776,1777,1779,1780,1786,1787, \\
1789,1791,1796,1799\end{array}$ \\
\hline & AD 1800 & $\begin{array}{l}1818,1822,1823,1881,1883,1884,1885, \\
1886,1887,1889\end{array}$ & $\begin{array}{l}1802,1803,1804,1805,1806,1808,1810,1812, \\
1813,1815,1824,1826,1827,1829,1831,1832, \\
1833,1834,1835,1836,1837,1838,1839,1840, \\
1842,1846,1849,1850,1855,1857,1860,1861, \\
1862,1865,1866,1868,1870,1871,1872,1875, \\
1877,1878,1879,1890,1891,1892,1896,1898, \\
1899\end{array}$ \\
\hline & AD 1900 & 1904 & $1900,1907,1908,1909,1910$ \\
\hline
\end{tabular}

Historical documentary records mainly came from chapter Benji and Wuxingzhi of Ming Shi (completed at AD 1739) and Qing Shi (completed at AD 1927), chapter Disasters and Prodigies of Qing Shi, also came from Donghua Lu, Donghua Xu Lu, Luzheng Xu Gao, Gansu Xing Tong Zhi, Draft of Whole Records of Gansu, and Abstract History of Gan Qing Ning Area, Shinianzu Sui Lu, Catalogue of Disasters in China, Brief Natural Disaster Records of each period of Gansu Province, Collection of weather records in China in the last 3000 years, Qingyangfu Zhi, Lintaofu Zhi, and Qinzhou Zhi, Andingxian Zhi, Gongchangfu Zhi. Chronicles of Lanzhou, Gaolan, Gulang, Daohe, Zhangxian, Pingliang, Jingyuan, Fuqiang, Zhengning are also referred to. 
Table 3. Examples of the D/F index classification.

\begin{tabular}{|c|c|c|}
\hline $\mathrm{D} / \mathrm{F}$ index & Year AD & Description \\
\hline 5 & 1485 & $\begin{array}{l}\text { Big drought in Pingliang, Gongchang (today's Longxi-authors), } \\
\text { Zhuanglang (Revised Zhenyuanxian Zhi, Vol. 18). } \\
\text { Big drought in Pingliang, Gongchang, and no crop grew over } \\
\text { thousands of miles, more than half of people and animals died } \\
\text { (Zhangxian Zhi, Vol. 7). }\end{array}$ \\
\hline 4 & 1076 & $\begin{array}{l}\text { Shaanxi was dry in August (Longxi belonged to Shaanxi in Ming } \\
\text { Dynasty-authors) (Song Shi, Vol. 66). }\end{array}$ \\
\hline 3 & 1321 & $\begin{array}{l}\text { Henan and Shaanxi were dry in spring and raining in autumn } \\
\text { (Yuan Shi, Vol. 28). }\end{array}$ \\
\hline 2 & 1654 & $\begin{array}{l}\text { Heavy rain in Lanzhou in February lasted for more than } 20 \text { days } \\
\text { (Qing Shi, Vol. 42). }\end{array}$ \\
\hline 1 & 1448 & $\begin{array}{l}\text { Rain in Shaanxi lasted for a long time during summer and } \\
\text { autumn, landslip occurred in Tongwei, Pingliang and Huating } \\
\text { (Ming Shi, Vol. 30). }\end{array}$ \\
\hline
\end{tabular}

large on the time scale and manifested a high degree of dryness. Records of cannibalism can be found everywhere. The droughts gave society a heavy blow, and the second one possibly constituted an important cause of the fall of the Ming Dynasty.

It was still dry in the Qing time. Table 2 shows that only in the 1650's, 1750' and 1880's did the weather conditions change. There were also two severe droughts in the Qing time. One lasted from the 1680's to the 1740's - about 60 years. The other lasted from the 1820's to the 1870's more than 50 years. Severe drought was also recorded in tree rings in the Northeast Tibetan plateau - from about AD 1580 to AD 1735 (Liu et al., 2006). The former drought did not bring much harm to society as it occurred during the famous "Period of Kangxi and Qianlong Prosperity". Historical documents recorded that appropriate countermeasures had been taken by the government, such as suspending taxes and doling out relief money. The latter, however, was a different matter. The strength of the nation had decreased after the "Period of Kangxi and Qianlong Prosperity", and the impact was now felt of the two opium wars (1840-1842; 1856-1860), the Taiping Tianguo Movement (1851-1864) and other peasant rebellions (Nian Army, Muslim Rebellion in Shaanxi \& Gansu). Countermeasures were powerless; and we read that in many places "bodies of persons who died from hunger filled the streets", "man ate man" and "persons exchanged their children and ate".

During the period of the Republic of China (AD 19121949), instrument records are available.

\section{Parameterization of historical climate records}

Historical climate records have accurate dates and clear climatic information, but they are usually qualitative descriptions. To compare them with records of other areas, they need to be parameterized. Since the 1970s, Chinese climatologists have cooperated to extract climatic information from more than 2000 kinds of historical documents over the last 500 years, beginning in AD 1470. They use the method of 5-level classification to estimate series of yearly drought/flood (D/F) levels in the principal rainy seasons at 120 sites throughout the entire country, and have gained great success (Central Meteorological Bureau, 1981).

As the climate reconstruction in this paper starts from AD 960 , with the scarcity of historical records in the early years, we first classify the records to 5 levels year by year as $\mathrm{D} / \mathrm{F}$ index, using traditional classification methods. The classification is mainly based on the time of occurrence, the affected area and the degree of drought and flood in spring, summer or autumn (Zhang, 1983). Detailed standards are as follows: Wet, heavy rain lasting a long time or occurring over a large area; Mildly wet, sustaining rain in spring or autumn that does not cause disaster or heavy rain break just in a local area; Fitting climate that gives rise to a big harvest year, or describes as rainy (dry) in spring but dry (rainy) in autumn; Mildly dry, seasonal drought within a month that does not cause disaster or severe drought just in a local area; Dry, severe drought that lasts several months, spans two seasons or occurs in a large area (Zhang, 1983). Since our research area is located in semi-arid zone, we have made small changes in these standards. When there were records like "Big harvest year", we consider the climate to be mildly wetter than in a normal year. Because the Longxi area is in Northwest China and historical documents are less here than in eastern and central China, we sometimes refer to historical climate records from neighboring areas. In this case, the D/F level will be assigned to the lower grade. Table 3 gives some examples of the classification.

We now introduce Yan's method to define the average D/F level (see Yan et al., 1991, 1993 for details). Considering 
the semi-arid condition of our studied area, the times and details of drought records are far more abundant than those of flood records. We have thus also made some revisions in this method, and define the average D/F index as follows:

$G i=\left\{\begin{array}{l}1, a \geq 0.7 \\ 0,0.4 \leq a \leq 0.6 \\ -1, a \leq 0.3\end{array}\right\}$

$a=N i / N, N i$ is the times of great drought in the $i$ th unit interval, $N$ is the sum of the times of great drought and great flood in the same interval. Moreover, we set up two subsidiary levels, $G i=0.5(0.6<a<0.7)$ and $G i=-0.5$ $(0.3<a<0.4)$. These two levels are used to describe the average $\mathrm{D} / \mathrm{F}$ status when both drought and flood occurred but great droughts (or great floods) were a little more than great floods (or great droughts).

Considering the document recorded places selected here are concentrated in a small area, when there were no great drought and great flood records, thus $N=0, G i$ mainly rest with minor drought and minor flood records. We also set $G i=1(-1)$ when there were only minor drought (flood) records with no great drought (flood) or flood (drought) records, and the years of minor droughts (floods) exceed half of the unit interval. If the years were not exceed the half, we set $G i=0.5(-0.5)$. When there were both minor drought records and minor flood records, if the droughts were more than the floods, we define $G i=0.5$, otherwise $G i=-0.5$. In this way, both great and minor disasters are taken into account. In this paper, we set the period interval as 10 years.

Meteorological precipitation records in our area started from 1937. In order to link these to the precipitation series reconstructed from historical documents, we first classify the yearly meteorological precipitation records to 5-levels (see Central Meteorological Bureau, 1981 and Zhang, 1983 for details). Then we calculate the average D/F level of every 10 years. When there are both meteorological precipitation records and historical climate records, we mainly use the meteorological records (Gong et al., 1983). The result of parameterization is shown in Fig. 2.

\section{Reliability test}

\subsection{Source of historical climate documents}

The historical documents used in this paper mainly came from two sources: official dynastic histories and official local chronicles. We believe that even though the official histories may contain some false statements for political reasons, the records on climate are reliable. As China is an agricultural country, agriculture was regarded as extremely important in each dynasty; and much attention was paid to climate disaster, especially when the country was stable and flourishing. To prevent mendacious reports of natural disasters, the records of some dynasties, such as the Qing, were recorded

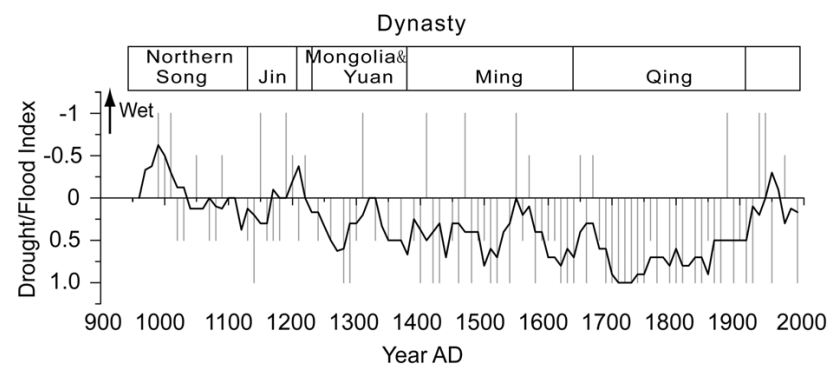

Fig. 2. 10-year averaged D/F series of Longxi since AD $960(-1$, wet; -0.5 , mildly wet; 0 , fitting climate; 0.5 , mildly dry; 1 , dry), the black line represents 5-point AA moving averaged result.

according to several different systems at the same time and were crosschecked (Gong et al., 1983).

Meteorological records appearing in local chronicles are also reliable, because they are mainly from local archives (Zhang, 1983). Many of the local chronicles cited in this paper were written in early years, such as Qingyangfu Zhi from the reign of Emperor JiaJing (AD 1522-1566) of the Ming Dynasty, Lintaofu Zhi from the reign of Emperor Wanli (AD 1573-1619) also of Ming, Andingxian Zhi and Gongchang fu Zhi from the reign of Emperor Kangxi (AD 1662-1722) of the Qing Dynasty. These books are thought to accurately record important climate changes in the area. Moreover, some great disasters appeared in different historical documents.

Thus, the historical meteorological records used in this paper are reliable.

\subsection{Historical climate referred sites}

Most parts of China are affected by the Asian monsoon, with precipitation concentrated mainly in May-October (Zhang, 1991). To test the rationality of historical climate referred sites, we therefore use the correlation coefficients of annual precipitation for May-October of Lanzhou, Longxi, Lintao, Tianshui, Pingliang and Longnan from 1945 to 2004 and for Zhangxian from 1967 to 2004 . We set the annual precipitation for May-October from 1945 to 2004 in Longxi County as the standard. Correlation analyses show that the precipitation for May-October of the other six sites is significantly correlated with those of Longxi County at 0.01 levels. The correlation shows that the selection of historical climate referred sites is reasonable.

\subsection{Result of parameterization}

The traditional 5-level classification method is mature in historical climatic research and has gained much success (Central Meteorological Bureau, 1981; Zhang, 1983; Zhang et al., 1997). Here we test the method of the 10-year averaged $\mathrm{D} / \mathrm{F}$ level. We unite the yearly $\mathrm{D} / \mathrm{F}$ level records of the last 500 years in Lanzhou (Central Meteorological Bureau, 1981) 


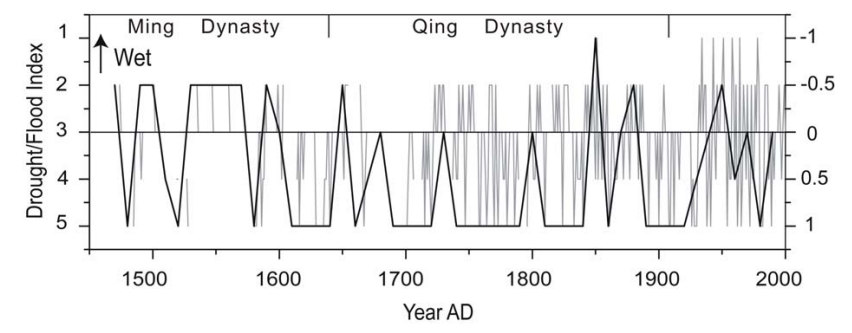

Fig. 3. Comparison of annual D/F series and 10-year averaged D/F series of Lanzhou, the grey line indicates annual D/F level, the black line represents 10-year averaged D/F level.

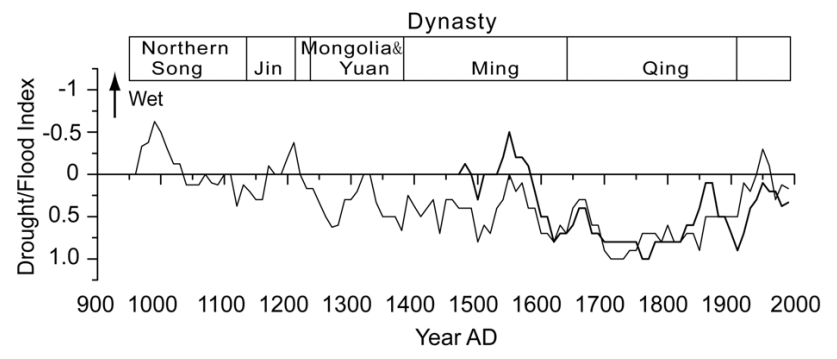

Fig. 4. Comparison of D/F series between Longxi and Lanzhou. The thin line represents 5-point AA moving averaged result of 10year averaged D/F series of Longxi, the thick line represents 5point AA moving averaged result of 10 -year averaged D/F series of Lanzhou.

using the method of the average D/F level to get a 10-year averaged D/F series (the black line in Fig. 3). From the comparison in Fig. 3, we can see that the averaged D/F series can truly reflect the primary D/F series (Fig. 3).

At the same time, from the comparison of the reconstructed average D/F series of Longxi and Lanzhou (Central Meteorological Bureau, 1981), we find they correlate well with each other in the last 500 years (Fig. 4).

\section{Discussion}

5.1 Comparisons among precipitation variations of Longxi since AD 960 and other climate records

Comparing the precipitation variations of Longxi since $\mathrm{AD}$ 960 with the precipitation variations of Dulan area, northeastern of the Tibetan Plateau reconstructed by tree rings (Liu et al., 2006) (Fig. 5), we find that the low frequency variations of these two series are well corresponded. This indicates that the precipitation in the northeast margin and the northeastern of the Tibetan Plateau varies synchronously on multi-decadal to centennial scales and that precipitation variations of these two areas are most likely controlled by same factors. At the same time, we compare the precipitation of the Longxi area with the temperature of the Northern

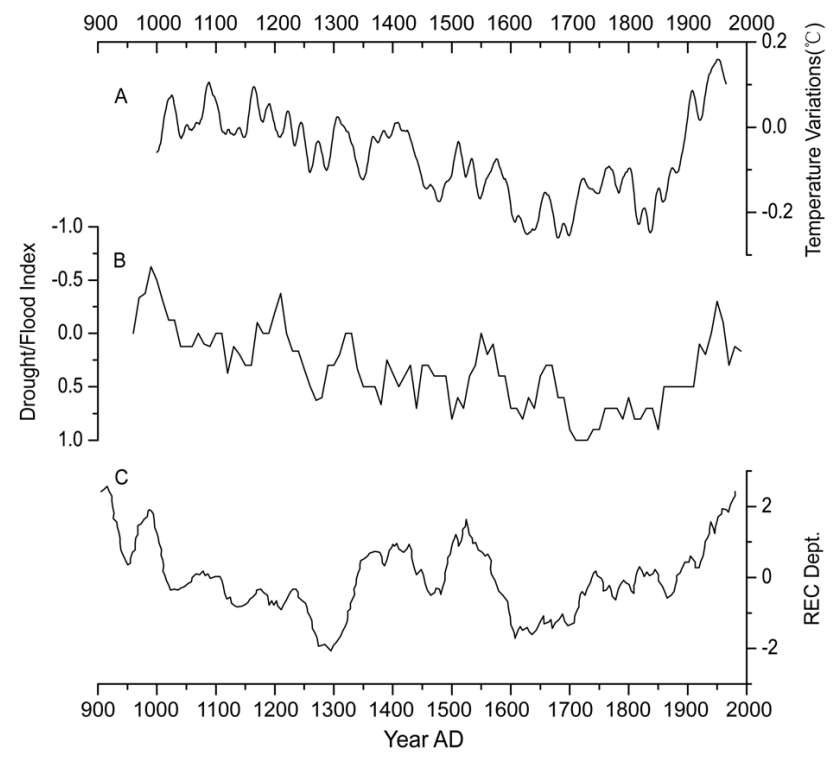

Fig. 5. Comparison of D/F series of Longxi (B), Northern Hemisphere temperature (A) (Crowley, 2000) and precipitation reconstructed series of Dulan (C) from tree rings after 40-year moving averaged (REC, the reconstructed curve) (Liu et al., 2006).

Hemisphere during the last millennium (Crowley, 2000). We find that both the trends and the main peaks correspond well in two series. High precipitation of Longxi corresponds to high temperature of the Northern Hemisphere, and low precipitation of Longxi corresponds to low temperature of the Northern Hemisphere (Fig. 5). This suggests that the precipitation variations of the northeast margin of the Tibetan Plateau have a close relationship with the temperature variations of the Northern Hemisphere on multi-decadal to centennial scales. Similar results were obtained from the study of the Dulan tree rings (Liu et al., 2006).

5.2 Driving force of precipitation variations of Longxi in the last millennium

The Longxi area is located in the eastern part of Northwest China and at the northern edge of the Asian summer monsoon (Qian, 2004). The precipitation here is affected by the Indian summer monsoon, the East Asia summer monsoon, the East Asia winter monsoon and the westerly jet. Tang (2006) studied the northern edge of the Asian summer monsoon in the Northwest China using meteorological data from 1951 to 2000. He found that precipitation on the eastern region of Northwest China and the location of the north edge of the Asian summer monsoon correlated positively with both the Indian summer monsoon index and the East Asian summer monsoon index. When the Indian summer monsoon and the East Asian summer monsoon are strong, the north edge lies more northward and the precipitation of the east region of Northwest China increases. On the contrary, when the 
Indian summer monsoon and the East Asian summer monsoon are weak, the north edge of the Asian summer monsoon lies more southward and precipitation of the eastern region of Northwest China decreases.

Many high resolution climate records both from ocean and continent show that solar activity drives the Holocene Asian summer monsoon variations on multi-decadal to centennial scales (von Rad et al., 1999; Wang and Sarnthein, 1999; Hong et al., 2001; Neff et al., 2001; Fleitmann et al., 2003; Dykoski et al., 2005; Wang et al., 2005; Dong et al., 2006). Carbon-14 $\left({ }^{14} \mathrm{C}\right)$ and beryllium-10 $\left({ }^{10} \mathrm{Be}\right)$ records are considered most reliable proxies of changes in solar activity (Hoyt and Schatten, 1997; Magny, 2004; Muscheler et al., 2007), although cosmogenic radionuclide records are also influenced by both the geomagnetic field and climate (Renssen et al., 2000; Muscheler et al., 2007). By considering multiple influencing factors, Muscheler et al. (2007) calculated two records of solar modulation function variability over the last millennium based on ${ }^{14} \mathrm{C}$ and ${ }^{10} \mathrm{Be}$ respectively, and found there was a good agreement between the two. The agreement suggests that the variations in these isotopes are primarily driven by solar activity (Muscheler et al., 2007). Here, we compare our precipitation records of Longxi with the atmospheric ${ }^{14} \mathrm{C}$ concentration (Stuiver et al., 1998), the averaged ${ }^{10} \mathrm{Be}$ record (Muscheler et al., 2007), the reconstructed solar modulation record (Muscheler et al., 2007), we find there is a good correlation between precipitation and solar activity on multi-decadal to centennial scales in the last millennium (Fig. 6). It is showed in Fig. 6 that there are five periods of minimal solar activity known as Oort (AD 1010-1050), Wolf (AD 1280-1340), Spoerer (AD 1420-1530), Maunder (AD 1645-1715) and Dalton (AD 1795-1820) during the last millennium. Each period of solar activity minimum corresponds to a dry period of Longxi and strong solar activity period corresponds to a wet period of Longxi area. The good correspondence shows that solar activity may be an important driving force of the precipitation variations of Longxi on multi-decadal to centennial scales in the last millennium. But there are also some disaccords in relative intensity of variations between precipitation of Longxi and solar activity. For example, solar activity was very strong at around AD 1800, but precipitation of longxi was not such high in this period, which indicates other factors such as changes in tropic coupled ocean-atmosphere system may also have influence in precipitation variations of Longxi.

5.3 Precipitation of Longxi, Northern Hemisphere temperature and solar activity

Numerous studies show that solar activity is the main force that drives regional climate changes in the Holocene (Kilian et al., 1995; Stuiver et al., 1997; van Geel et al., 1999; Yu and Ito, 1999; Crowley, 2000; Hong et al., 2000; Perry and Hsu, 2000; Bond et al., 2001; Hodell et al., 2001; Neff et al., 2001; Speranza et al., 2002; Fleitmann et al., 2003; Frisia et al.,

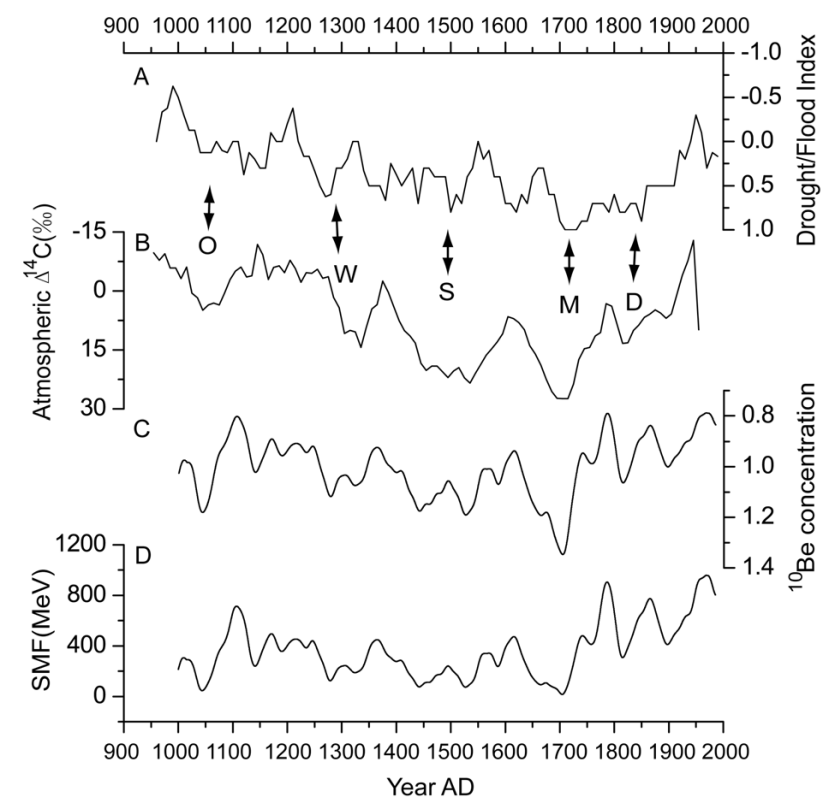

Fig. 6. Comparison of variations between precipitation of Longxi and solar activity since AD 960. The atmospheric ${ }^{14} \mathrm{C}$ (after removal of linear trend) comes from Stuiver et al. (1998) (B), the averaged ${ }^{10} \mathrm{Be}$ concentration (normalized) $(\mathbf{C})$ and the reconstructed solar modulation function(SMF) (D) come from Muscheler et al. (2007). The letters O, W, S, M, D in (B) represent five minima of solar activity known as Oort (AD 1010-1050), Wolf (AD 1280-1340), Spoerer (AD 1420-1530), Maunder (AD 1645-1715) and Dalton (AD 1795-1820) during the last millennium.

2003; Hu et al., 2003; Magny, 2004; Kilcik, 2005; Ogurtsov et al., 2005; Wang et al., 2005; Xu et al., 2006; Barron and Bukry, 2007; Haltia-Hovi et al., 2007; Rodolfo Rigozo et al., 2007). The synchronous variations of the precipitation of Longxi and the Northern Hemisphere temperature on multidecadal to centennial scales may be ascribed to the same control of solar activity. Solar activity variability can not only change the total solar irradiance on the earth that directly affects the earth surface temperature, but the variability can be also remarkably amplified by changes of ultraviolet radiation and clouds (Ney, 1959; Pudovkin and Raspopov, 1992; Haigh, 1999; Shindell et al., 1999; van Geel et al., 1999; Tinsley, 2000). Therefore, a small degree of solar variation may thus lead to noteworthy variation in the earth's surface temperature. The mechanism for solar activity driving precipitation of Longxi is probably as follows: Since oceanic and terrestrial heat capacity are different, when solar activity increases, the temperature of land increases quickly. The Tibetan Plateau further magnifies such differences between the Asian continent and its surrounding ocean. The Asian summer monsoon is strengthened and the East Asian winter monsoon is weakened, which lead northward moving of the north edge of Asian summer monsoon. At the same time, the increase of solar activity forces the westerlies to move 
northward (Haigh, 1996), so that the Asian summer monsoon will move northward into the northwest inner land and bring rainfall there. Contrariwise, when solar activity weakens, the temperature of land decreases quickly, the winter monsoon is strengthened (Xiao et al., 2006), the summer monsoon is weakened, the north edge of the Asian summer monsoon and westerlies move southward synchronously, causing a decrease in the precipitation of Longxi.

\section{Conclusions}

Generally speaking, the climate of Longxi since AD 960 has been gradually drier with fluctuations, reaching the driest period from the end of the 17th century to the 18th century. After this period, precipitation gradually increased in fluctuations. There were only three short wet periods: from the end of the 10th century to the early years of the 11th century, from the end of the 12th century to the early years of the 13th century and during the first half of the 20th century.

Precipitation variations of the northeast margin of the Tibetan Plateau and the northeastern part of the Tibetan Plateau are consistent in the last millennium and correspond well with average temperature variations in the Northern Hemisphere on multi-decadal to centennial scales. Good coherences among the precipitation variations of Longxi and variations of atmospheric ${ }^{14} \mathrm{C}$ concentration, the averaged ${ }^{10} \mathrm{Be}$ record and the reconstructed solar modulation record show that solar activity may be an important driving force of precipitation variations of Longxi area on multi-decadal to centennial scales in the last millennium. Synchronous variations between Longxi precipitation and Northern Hemisphere temperature may be ascribed to solar activity. Solar activity controls the south to north motion of north edge of the Asian summer monsoon by affecting the Asia summer monsoon intensity, the East Asian winter monsoon intensity and the locations of westerlies, thus further dominates precipitation variations of Longxi.

Acknowledgements. This paper benefits from two anonymous reviewers' and J. Fei's constructive suggestions. We thank R. Muscheler for providing the ${ }^{10} \mathrm{Be}$ data and solar modulation function data. We also wish to thank $\mathrm{H}$. Xu, J. Chen and H. Long for their help in this work. This study is supported by the National Basic Research Program of China grant 2004CB720206; National Science Foundation of China grants 40403001 and 40531003; State Key Laboratory of Loess and Quaternary Geology of China grant SKLLQG 0615.

Edited by: D.-D. Rousseau

\section{References}

An, C. B., Feng, Z. D., Tang, L. Y., and Chen, F. H.: Environmental change and cultural transition at $4 \mathrm{cal}$. Ka BP in central Gansu, Acta. Geogr. Sin., 58(5), 743-748, 2003 (in Chinese with English abstract).

Barron, J. A. and Bukry, D.: Solar forcing of Gulf of California climate during the past $2000 \mathrm{yr}$ suggested by diatoms and silicoflagellates, Mar. Micropaleontol., 62(2), 115-139, 2007.

Bond, G., Kromer, B., Beer, J., Muscheler, R., Evans, M. N., Showers, W., Hoffmann, S., Lotti-Bond, R., Hajdas, I., and Bonani, G.: Persistent solar influence on North Atlantic climate during the Holocene, Science, 294, 2130-2136, 2001.

Bradley, R. S. and Jones, P. D.: When was the 'Little Ice Age'? in: Proceedings of the International Symposium on the "Little Ice Age", edited by: Mikame, T., Tokyo Metropolitan University, Tokyo, Japan, 1-4, 1992.

Central Meteorological Bureau: Atlas of flood and drought in China in the last 500 years, Map Press, Beijing, China, 1981 (in Chinese).

Chen, G. Y.: Catalogue of disasters in China, Shanghai Press, Shanghai, China, 1939 (in Chinese).

Crowley, T. J.: Causes of climate change over the past 1000 years, Science, 289, 270-277, 2000. Data archived at the World Data Center for Paleoclimatology, Boulder, Colorado, USA.

Deng, T.: Rescue history of China, The Commercial Press, Shanghai, China, 40-48, 1937 (in Chinese).

Dong, J. G., Kong, X. G., and Wang, Y. J.: The East Asian Monsoon climate changes at Mt. Shennongjia and its relation to shift of Intertropical Convergence Zone during the Holocene, Quaternary Sci., 26(5), 827-834, 2006 (in Chinese with English abstract).

Dykoski, C. A., Edwards, R. L., Cheng, H., Yuan, D. X., Cai, Y. J., Zhang, M. L., Lin, Y. S., Qing, J. M., An, Z. S., and Revenaugh, J.: A high-resolution, absolute-dated Holocene and deglacial Asian monsoon record from Dongge Cave, China, Earth Planet. Sci. Lett., 233(1-2), 71-86, 2005.

Fleitmann, D., Burns, S. J., Mudelsee, M., Neff, U., Kramers, J., Mangini, A., and Matter, A.: Holocene forcing of the Indian Monsoon recorded in a stalagmite from southern Oman, Science, 300, 1737-1739, 2003.

Frisia, S., Borsato, A., Preto, N., and McDermott, F.: Late Holocene annual growth in three Alpine stalagmites records the influence of solar activity and the North Atlantic Oscillation on winter climate, Earth Planet. Sci. Lett., 216(3), 411-424, 2003.

Gong, G. F., Zhang, P. Y., Wu, X. D., and Zhang, J. R.: Research methods of climate changes in historical time, Science Press, Beijing, China, 18-56, 1983 (in Chinese).

Haigh, J. D.: The impact of solar variability on climate, Science, 272, 981-984, 1996.

Haigh, J. D.: Modelling the impact of solar variability on climate, J. Atmos. Sol.-Terr. Phy., 61(1), 63-72, 1999.

Haltia-Hovi, E., Saarinen, T., and Kukkonen, M.: A 2000-year record of solar forcing on varved lake sediment in Eastern Finland, Quaternary Sci. Rev., 26(5-6), 678-689, 2007.

Hodell, D. A., Brenner, M., Curtis, J. H., and Guilderson, T.: Solar forcing of drought frequency in the Maya lowlands, Science, 292, 1367-1370, 2001.

Hong, Y. T, Liu, D. S., Jiang, H. B.,, Zhou, L. P., Beer, J., Hong, B., Zhu, Y. X., Li, H. D, Leng, X. T., Qin, X. G., Wang, Y., Lin, Q. H., and Zeng, Y. Q.: Evidence for solar forcing of climate 
variation from $\delta^{18} \mathrm{O}$ of peat cellulose, Sci. China(Ser. D), 43(2), 217-224, 2000.

Hong, Y. T., Wang, Z. G., Jiang, H. B., Lin, Q. H., Hong, B., Zhu, Y. X., Wang, Y., Xu, L. S., Leng, X. T., and Li, H. D.: A 6000-year record of changes in drought and precipitation in northeastern China based on a $\delta^{13} \mathrm{C}$ time series from peat cellulose, Earth Planet. Sci. Lett., 185(1-2), 111-119, 2001.

Hoyt, D. V. and Schatten, K. H.: The Role of the Sun in Climate Change, Oxford University Press, Oxford, 279 pp., 1997.

Hu, F. S., Kaufman, D., Yoneji, S., Nelson, D., Shemesh, A., Huang, Y., Tian, J., Bond, G., Clegg, B., and Brown, T.: Cyclic variation and solar forcing of Holocene climate in the Alaskan subarctic, Science, 301, 1890-1893, 2003.

Kilcik, A.: Regional sun-climate interaction, J. Atmos. Sol.-Terr. Phy., 67(16), 1573-1579, 2005.

Kilian, M. R., van der, P. J., and van Geel, B.: Dating raised bogs: new aspects of AMS ${ }^{14} \mathrm{C}$ wiggle matching, a reservoir effect and climatic change, Quaternary Sci. Rev., 14(10), 959-966, 1995.

Lamb, H. H.: The early medieval warm epoch and its sequel, Palaeogeogr. Palaeocl., 1, 13-37, 1965.

Li, J. Z., Wang, D. Q., and Liu, B.C.: Commentary on Dufu's poetries, Gansu People's Press, Lanzhou, China, 122, 180, 251, 269 pp., 1985 (in Chinese).

Liu, Y., An, Z. S., Ma, H. Z., Cai, Q. F., Liu, Z. Y., Kutzbach, J. K., Shi, J. F., Song, H. M., Sun, J. Y., Yi, L., Li, Q., Yang, Y. K., and Wang, L.: Precipitation variation in the northeastern Tibetan Plateau recorded by the tree rings since $850 \mathrm{AD}$ and its relevance to the Northern Hemisphere temperature, Sci. China (Ser. D), 49(4), 408-420, 2006.

Liu, Y. F.: Draft of whole records of Gansu, 1936, in: Document series of Northwest china(27), edited by: Wu, J.,Lanzhou Historical Document Press, Lanzhou, China, 1990 (in Chinese).

Magny, M: Holocene climate variability as reflected by midEuropean lake-level fluctuations and its probable impact on prehistoric human settlements, Quaternary Int., 113(1), 65-79, 2004.

Mu, S. Q.: Abstract history of Gan Qing Ning area, Junhua Press, Lanzhou, China, 1936 (in Chinese).

Muscheler, R., Joos, F., Beer, J., Muller, S. A., Vonmoos, M., and Snowball, I.: Solar activity during the last $1000 \mathrm{yr}$ inferred from radionuclide records, Quaternary Sci. Rev., 26(1-2), 82-97, 2007.

Neff, U., Burns, S. J., Mangini, A., Mudelsee, M., Fleitmann, D., and Matter, A.: Strong coherence between solar variability and the monsoon in Oman between 9 and 6 kyr ago, Nature, 411, 290-293, 2001.

Ney, E. P.: Cosmic radiation and the weather, Nature, 183, 451-452, 1959.

Ogurtsov, M. G., Helama, S., Eronen, M., and Lindholm, M.: Centennial-to-millennial fluctuations in July temperatures in North Finland as recorded by timberline tree rings of Scots pine, Quaternary Res., 63(2), 182-188, 2005.

Perry, C. A. and Hsu, K. J.: Geophysical, archeological, and historical evidence support a solar-output model for climate change, PNAS, 97(23), 12 433-12 438, 2000.

Pudovkin, M. I. and Raspopov, O. M.: The mechanism of action of solar activity on the state of lower atmosphere and meteorological parameters, Geomag. Aeron., 32, 593-608, 1992.

Qian, W. H.: Meteorology, Peking university Press, Beijing, China,
185-186, 2004 (in Chinese).

Renssen, H., Geel, B.v., Plicht, J.v.d., and Magny, M.: Reduced solar activity as a trigger for the start of the Younger Dryas?, Quaternary Int., 68-71, 373-383, 2000.

Rodolfo Rigozo, N., Roger Nordemann, D. J., Evangelista da Silva, H., Pereira de Souza Echer, M., and Echer, E.: Solar and climate signal records in tree ring width from Chile (AD 1587-1994), Planet. Space Sci., 55, 158-164, 2007.

Shindell, D., Rind, D., Balachandran, N., Lean, J., and Lonergan, P.: Solar cycle variability, ozone and climate, Science, 284, 305308, 1999.

Speranza, A., Van Geel, B., and Van der Plicht, J.: Evidence for solar forcing of climate change at ca. $850 \mathrm{cal} \mathrm{BC}$ from a Czech peat sequence, Global Planet. Change, 35(1), 51-65, 2002.

Stuiver, M., Braziunas, T. F., Grootes, P. M., and Zielinski, G. A.: Is there evidence for solar forcing of climate in the GISP2 oxygen isotope record?, Quaternary Res., 48(3), 259-266, 1997.

Stuiver, M., Reimer, P. J., Bard, E., Beck, J. W., Burr, G. S., Hughen, K. A., Kromer, B., McCormac, G., van der Plicht, J., and Spurk, M.: INTCAL98 radiocarbon age calibration, 24000-0 cal BP, Radiocarbon, 40(3), 1041-1083, 1998.

Tan, M. and Cai, B.: Preliminary calibration of stalagmite oxygen isotopes from eastern monsoon China with northern Hemisphere temperatures, Pages News, 13(2), 16-17, 2005.

Tang, K. J. and Liu, J. L.: Collection of historical material of Tubo in the period of Song Dynasry(1), Sichuan National Press, Chengdu, China, 1986 (in Chinese).

Tang, X.: Study on the north edge of summer monsoon over Northwest China, Doctoral dissertation of Peking University, 2006 (in Chinese).

Tinsley, B. A.: Influence of solar wind on the global electric circuit, and inferred effects on cloud microphysics, temperature and dynamics in the troposphere, Space Sci. Rev., 94(1-2), 231-258, 2000.

van Geel, B., Raspopov, O. M., Renssen, H., van der Plicht, J., Dergachev, V. A., and Meijer, H. A. J.: The role of solar forcing upon climate change, Quaternary Sci. Rev., 18(3), 331-338, 1999.

von Rad, U., Schaaf, M., Michels, K. H., Schulz, H., Berger, W. H., and Sirocko, F.: A 5000-yr record of climate change in varved sediments from the oxygen minimum zone off Pakistan, north eastern Arabian Sea, Quaternary Res., 51(1), 39-53, 1999.

Wang, L. and Sarnthein, M.: Holocene variations in Asian monsoon moisture: a bidecadal sediment record from the South China Sea, Geophys. Res. Lett., 26(18), 2889-2892, 1999.

Wang, Y. J., Cheng, H., Edwards, R. L., He, Y. Q., Kong, X. G., An, Z. S., Wu, J. Y., Kelly, M. J., Dykoski, C. A., and Li, X. D.: The Holocene Asian Monsoon: links to solar changes and North Atlantic climate, Science, 308, 854-857, 2005.

Xiao, S. B., Li, A. C., Liu, J. P., Chen, M. H., Xie, Q., Jiang, F. Q., Li, T. G., Xiang, R., and Chen, Z.: Coherence between solar activity and the East Asian winter monsoon variability in the past 8000 years from Yangtze River-derived mud in the East China Sea, Palaeogeogr. Palaeocl., 237(2-4), 293-304, 2006.

Xu, H., Hong, Y. T., Lin, Q. H., Zhu, Y. X., Hong, B., and Jiang, H. B.: Temperature responses to quasi-100-yr solar variability during the past 6000 years based on $\delta^{18} \mathrm{O}$ of peat cellulose in Hongyuan, eastern Qinghai-Tibet Plateau, China, Palaeogeogr. Palaeocl., 230(1-2), 155-164, 2006.

Yan, Z. W., Ye, D. Z., and Wang, C.: Climatic jumps in the 
flood/drought historical chronology of central China, Clim. Dynam., 6(3-4), 153-160, 1991.

Yan, Z. W., Li, S. Y., and Wang, X. C.: An analysis of decade-tocentury-scale climatic jumps in history, Sci. Atmos. Sin., 17(6), 663-672, 1993 (in Chinese with English abstract).

Yu, Z. C. and Ito, E.: Possible solar forcing of century-scale drought frequency in the northern Great Plain, Geology, 27(3), 263-266, 1999.

Zhang, D. E.: The method for reconstruction of climate series for the last 500 years and its reliability, in: Collected Papers of Meteorological Science and Technology (4), edited by: Central Meteorological Bureau, Meteorological Press, Beijing, China, 17-26, 1983 (in Chinese).

Zhang, D. E., Liu, C. Z., and Jiang, J. M.: Reconstruction of six regional dry/wet series and their abrupt changes during the last 1000 years in east China, Quaternary Sci., 1, 1-11, 1997 (in Chinese with English abstract).
Zhang, D. E.: Collection of weather records in China in the last 3000 years, Jiangsu Education Press, Nanjing, China, 2004 (in Chinese).

Zhang, J. C. (Ed.): China climate pandect, Meteorological Press, Beijing, China, 125-148, 1991 (in Chinese).

Zhao, S. Y.: Brief natural disaster records of each period of Gansu Province, Gansu People's Press, Lanzhou, China, 1984 (in Chinese).

Zhu, S. G., Wang, Y. L., and Hu, L. G..: Study on climate variation in the region of GuanZhong in the historical period, Quaternary Sci., 1, 1-11, 1998 (in Chinese with English abstract). 